\title{
A Systematic Review of the Influence of Taxation on Corporate Capital Structure
}

\author{
Submitted 14/02/20, $1^{\text {st }}$ revision 05/03/20, $2^{\text {nd }}$ revision 30/03/20, accepted 10/04/20

\section{Peter Vaz da Fonseca ${ }^{1}$, Andrea Decourt Savelli ${ }^{2}$, Michele Nascimento Jucá ${ }^{3}$}

\begin{abstract}
:
Purpose: The aim of this paper is a systematic review of the corporate finance literature on tax and capital structure since the complexity of legislation on taxation. It is a challenge for to researchers to understand the influence of this legislation on corporate financing.

Approach/Methodology/Design: A systematic review is a useful and important tool to check what has being studied and what are the gaps on the specific subject. Therefore, the study provides an examination of a sample of 33 most cited articles in the period from 2013 to 2017 that have been published in the main international financial journals. It is assumed that this analysis is sufficiently robust to support and contribute to the knowledge gaps identification.

Findings: It presents the most relevant papers about the influence of taxes on corporate capital structure, classifies and codifies the various characteristics of these articles, describes the strengths and the weaknesses of the studies in the available literature, and provides an agenda and a research framework to address the key gaps in the current knowledge on the theme.

Practical Implications: The study will contribute positively to the understanding of foreign direct investment for the governments, world organizations, academia, companies and investors.

Originality/Value: To the best of the authors' knowledge, this is the first systematic review identifying what is missing in the literature on taxation and capital structure.
\end{abstract}

Keywords Taxes, corporate finance, capital structure, systematic literature review.

JEL codes: H20, G30, G32.

Paper Type: Literature review study.

\footnotetext{
${ }^{l}$ Department of Business, Mackenzie Presbyterian University, e-mail: peterfonseca67@gmail.com

${ }^{2}$ Department of Business, Mackenzie Presbyterian University, e-mail: deadecourt@gmail.com

${ }^{3}$ Department of Business, Mackenzie Presbyterian University, e-mail: michele.jucá@mackenzie.br
} 


\section{Introduction}

Modigliani and Miller (1958) demonstrate that the financing structure is irrelevant to the company's value, establishing, from this proposition, the basis of the modern theory on capital structure. Such statement presupposes the existence of a perfect world, with no frictions, including the non-existence of taxation. In 1963, the authors review the premise of the non-existence of taxes for legal entities and they complement the previous assumption. They recognize that the debt tax benefits increase the company's value, indicating that it should seek greater leverage. However, Miller, in 1977, adds to the topic the consideration of individual's taxation, ratifying the propositions of the 1958 seminal article.

Barclay, Heitzman and Smith (2013) synthesize the relevance of this discussion by highlighting the core question on the existence or otherwise of an optimal capital structure of firms. In other words, they inquire how could investment financing be divided between equity and third party capital to maximize the company's value? On the one hand, debt contracting brings the benefit of interest deductibility for income tax purposes. The company saves the tax portion that falls on the interest payment. However, on the other hand, indebtedness increases the bankruptcy risk. Such off-set encourages financial leverage to the point on which tax benefit is outweighed by the risk and by the associated bankruptcy cost (Myers, 1984).

Fama (2011) points out that a challenge still open in the literature is to produce evidence about how taxes influence optimal financing decisions. Heider and Ljungqvis (2015) state that this theme remains subject to discussion. Doidge and Dyck (2015) argue that researchers are concerned about the relation between taxes and corporate policies. For Inger (2013), the corporate tax reduction should increase the shareholders' wealth, in as much as the present value of expected future dividends increases. Yet, Myers et al. (1998) are more skeptical, stating that taxes are of third- order importance for the financing decision making.

This article aims to present a systematic review of the literature on the impact of corporate taxes on companies' capital structure (Arvanitis et al., 2012). Thus, the initial challenge of this research is to identify relevant works and knowledge gaps, taking into account the various theoretical models and existing empirical studies. The final expectation is to identify new perspectives on this matter. The period of five years (2013-2017) is considered in order to point the current gaps which still remain unanswered since the seminal works to date. However, it is important to note that it takes an article a minimum term of one year to be cited by other authors, that's why the most recent paper analyzed in this study dates from 2016.

Tranfield et al. (2003) argue that, in the literature review, the researcher maps and evaluates the relevant intellectual territory to specify a research issue that develops the knowledge even more. An alternative for the literature review is the scientific systematic review method for seeking and analyzing articles on a particular area of 
science, which aims at defining the limit of the research that one wishes to develop from a scientific perspective. It differs from the traditional way by adopting a transparent, replicable and scientific process, besides allowing to identifying scientific contributions related to a certain subject.

The challenges are: a) to identify the most relevant papers which describe the influence of taxes on corporate capital structure; b) to classify and codify the various characteristics of these articles; c) to present a brief summary of the contribution of each article; d) to describe strengths and weaknesses of studies in the available literature; e) to provide an agenda and a research framework to address the key gaps in the current knowledge on the theme.

Literature review is in section 2. The methodology used in this study is presented in section 3. In section 4 are the classification and coding used. Section 5 highlights the results of the research. Finally, section 6 points out the main conclusions, limitations and suggestions for future works.

\section{Literature Review}

A core question of corporate finance, with respect to optimal capital structure, is: given the capital needed to support the firm's investment activities and needs, how financing can be divided between equity and third-party capital to maximize the company's value? This question leads to another: what are the relevant factors to determine the optimal indebtedness for a particular company? (Barclay et al., 2013). In fact, if financing were always available in fair terms, venture capital would be for free and there would be no need to allocate it. However, as Erel et al. (2015) note, it is expensive. Thus, the authors clarify how taxes and capital risk costs should be allocated. It is known that the taxable basis allows to constituting a tax advantage of the debt, whose value depends on the level of the income tax rate (Modigliani and Miller, 1963). The trade-off theory (TOT) uses the debt tax advantage and the costs associated with bankruptcy risks as fundamental arguments for the existence of an optimal level of debt (DeAngelo and Masulis, 1980). In this context, a reduction in tax burden should also reduce the benefits of third-party capital (Wang et al., 2015).

Heider and Ljungqvist (2015) clarify the main differences between static and dynamic TOT. In static TOT, there is a preset of the optimal value of company's indebtedness, by maximizing the difference between the debt tax benefit and the expected bankruptcy cost. In dynamic TOT, rather than a rigid definition of the optimal level of capital structure, the company adjusts it according to the variation of taxes and of the cost of capital. Thus, whenever the marginal tax rate changes, the optimum level of indebtedness follows this variation in the same direction.

The results obtained by Faccio and $\mathrm{Xu}$ (2015) indicate that taxation on entities and individuals plays a significant role in the choice of corporate capital structure. They state that institutions tend to increase financial leverage after an increase in corporate 
direct taxes or after the rate raising on the dividends receipt by shareholders (Liapis et al., 2020). By means of taxation, governments extract a considerable part of the companies' cash flow in their jurisdictions. However, most countries allow companies to deducting interest expenses from their taxable income. Such deductions enable companies to protect income from corporate taxation and, at least theoretically, to increase the company's value.

Pfaffermayr et al. (2013) identify a positive interaction between corporate taxation and company age. The impact of corporate taxation on debt increases throughout the company's lifetime. First, they verify the existence of a positive relationship between taxation and the indebtedness level of a company, suggesting that tax system provides a systematic incentive for greater financial leverage. They, then, show that the age of the company has a negative impact on the debt proportions, which reveals that older companies are less dependent on debt than younger ones. Finally, the authors note a positive relationship between taxation and the age of companies. The result implies that the debt ratio of older firms is more intensively affected by a reduction in corporate tax rates than on younger firms.

As observed by Wang et al., 2015, some authors contest TOT by suggesting that corporate tax benefit would be offset or reversed by personal taxes (Miller, 1977). Others propose that behavior based on asymmetric information between managers and investors is the true driver of capital structure (Myers, 1984; Myers and Majluf, 1984). The main inference of the model proposed by Lin et al. (2014) is that many companies could use less debt than foreseen by traditional TOT models. Graham et al. (2015) demonstrate that the traditional empirical models of capital structure, based on the characteristics of firms, are insufficient to account for their tendency. They point out that there are changes in economic environment that increase the willingness of companies to issue or the willingness of investors to hold corporate debt securities.

Among these changes, the increase in corporate tax rates, the reductions in economic uncertainty, the growth in financial intermediation and the reduction of government indebtedness, are highlighted. The empirical outcomes by Buettner and Wamser (2013) confirm the significant effects of the host country tax rate and of that smaller one, in a group of multinational corporations on the use of domestic debt. They support the view that domestic debt is used to transfer taxable profits to low-taxation countries. However, the authors indicate that the tax effects magnitude is small. According to Egger et al. (2014), previous studies concentrate mainly on the tax responses of internal loans of the unit whose incentive is maximum.

However, internal capital markets make tax effects predictions more complex than reported in the literature. Examples include legal incentives, institutional weakness, financial underdevelopment and productivity (Jędrzejowska-Schiffauer et al., 2019). Tax benefits can encourage affiliates in higher rates countries to lend to affiliates in lower tax rates countries. Custódio and Metzger (2014) analyze the role of financial 
managers specialized in non-financial corporations. The result indicates that those companies led by these professionals tend to hold less cash, more debt and to become more involved in share repurchases.

Debt is a first-order determinant of capital structure, as observed by DeAngelo and Masulis (1980). However, the use of non-debt tax deductions may moderate the relevance of interest expenses in defining the optimal level of indebtedness. In addition, the extent of the benefit of a company's interest tax deductions also depends on how much it has in non-tax deductions. Nevertheless, while increasing financial leverage will lower corporate taxes, it also increases the aggregate taxes paid by its investors. Because they care about their post-tax returns, investors require compensation for increased taxes in the form of higher yields on corporate debt (Barclay et al., 2013).

At last, the results of the study by Barclay et al. (2013) indicate that debt costs and benefits are closely related to the nature of the company's assets and investments and that debt tax deductibility, at best, plays a secondary role in the firm's leverage decision. Hasan et al. (2014) provide comprehensive and consistent evidence that a higher level of tax evasion may lead to an increase in the cost of third-party capital. The analysis by Bessler et al. (2013) offers some explanations for the phenomenon of zero-leverage. They note that countries with a common law background - with high creditor protection and a dividend tax system, including Australia, Canada, Ireland, the United States and England - have a higher percentage of zero-leverage companies. Their conclusion is that firms can become debt free because they get their tax deductions from non-debt sources.

\section{Methodology}

Denyer and Tranfield (2009) define systematic review as a specific method of locating existing studies, selection and evaluation of contributions, analysis and synthesis of information and evidence description, to allow clear and reliable conclusions about the subject under study. Tranfield et al. (2003) state that the reviewer defines the appropriate research sequences for the study. The seeking strategy is reported in sufficient detail to ensure the research to be replicated. The research result should be a complete list of papers on which the review is based. Only studies meeting all the inclusion criteria specified in the review protocol are incorporated. The strict criteria used in the systematic review are linked to the aim at basing the analyses on the best quality evidence. The study involves the following steps:

Step 1: Checking of strengths and weaknesses of each database. Consideration of scope, total period for data capture, simple and advanced seeking methods, information clarity provided, and presence of citation ranking. This step is performed to confirm whether the same seeking parameters are used identically 
across all databases. The choice of the period between 2013 and 2017 is due to the greatest dynamic of recent tax changes all over the world.

Step 2: Use of research parameters. Taxes and capital structure are topics that encompass different areas of knowledge. To limit the scope of the study, a keyword research is performed in the following order, taxes and capital structure. It is worth to note that, despite using these keywords, there is a natural selection of their synonyms in the literature. Subsequently, the source filters of Scopus and Web of Science (WoS) bases are applied: language - English, type of material - complete articles of scientific journals, period 2013 to 2017 and areas of concentration economics, econometrics and finance, business and management on Scopus and economics, business finance, business, management and accounting on WoS. At first, 227 and 261 articles are found on Scopus and WoS, respectively. After the exclusion of those duplicates in both databases, 365 articles remain. From these, the ones with the greatest impact are identified according to the number of citations - see step 3 .

Step 3: Selection of the most cited articles. Articles are ordered based on the number of citations and then, a cut is made to select those contemplating $80 \%$ of the accumulated citations, totalling 78 articles. Thus, the works published during the period considered (January, 2013 to December, 2017), which are not among those $80 \%$, are not included in the initial sample. Such a measure is justified, since the number of times an article is cited demonstrates its relevance and recognition by the scientific community (Bornmann et al., 2010). In cases on which there is duplicity of papers citation in both bases, the number of citations defined by WoS is considered.

Step 4: Database creation and collection of articles. The 78 articles are obtained from the following academic research bases: Science Direct, EBSCO, ProQuest, JSTOR and Google academic. From them, the following information is collected to capture the general paper data: the article's title, author's name, affiliation institution and country of origin of the authors/researchers, journal's name, volume, issue number, initial and final page, publication year, data's country of origin and number of years of sample data, keywords, Digital Object Identifier (DOI), Journal of Economic Literature (JEL) and number of article citations on WoS and Scopus databases.

Step 5: Exclusion of non-concerned articles. An initial reading of the summary, introduction and conclusion of the articles is carried out to verify whether they are in accordance with the defined theme - taxes and capital structure of companies. Those not aligned with the mentioned theme are excluded. Among the 45 excluded articles, 8 are so for referring to financial institutions, 3 because they treat on individuals' taxation, 24 for not considering the capital structure as a dependent variable, 6 for they do not have taxes as an independent variable and 4 because they are not really articles, but rather book chapters, theoretical essays, and working papers. At the end of this process, 33 articles are identified. Then, their complete reading is done. 
Step 6: Reading and coding of papers. Papers are read for the purpose of identifying their aims, contributions and results. In addition, they are classified and codified into categories and subcategories structured according to the most common topics. Thus, they are classified into 9 categories, each of which has non-exclusive subcategories. It means that the same article can be positioned in more than one subcategory, which allows the sum to being greater than $100 \%$. The categories and their respective subcategories are shown in Table 1.

Step 7: Descriptive statistics. Database (step 4) is subjected to a frequency count to identify information, patterns and content gaps. It should be noted that in the analysis of the keywords, due to their variety, there is a consolidation of 8 groups: capital structure, taxation, sample type, determinants of capital structure, theories, methodology, cost of capital and others.

\section{Classification and Coding}

Classification is one of the most relevant aspects of systematization, as it identifies the main features of the papers under review. It is worth mentioning that the present one is based on the works by Jabbour (2013), Barboza et al. (2016) and Nazário et al. (2017). The data identified and collected in Step 4 above referring to authors/researchers and journals, such as paper's title, authors/researchers' name, affiliation, institution and country of origin, journal's name, volume, number, first and end page, year of publication, country of origin and number of years of sample data, keywords, DOI, JEL and number of article citations on WoS and Scopus databases, are now classified in categories and subcategories. After the analyses of the 78 papers, 45 papers unrelated to the theme are identified, and, therefore, excluded from the final sample. For the remaining 33 articles, 9 categories - based on the classification of mentioned authors above - are structured, and for each of them, the subcategories described in Table 1 are established. Subcategories, in turn, are defined based on the most frequent concepts identified in the articles.

Table 1. Definition of Categories and Subcategories of Articles' Analysis

\begin{tabular}{|c|c|c|c|c|}
\hline \multicolumn{2}{|c|}{ Categories } & \multicolumn{3}{|c|}{ Subcategories } \\
\hline \# & Name & $\#$ & Name & Description \\
\hline \multirow{3}{*}{1} & \multirow{3}{*}{$\begin{array}{l}\text { Main } \\
\text { topics/ } \\
\text { focus of } \\
\text { the } \\
\text { study }\end{array}$} & A & $\begin{array}{l}\text { Capital } \\
\text { Struture and } \\
\text { cost of capital }\end{array}$ & $\begin{array}{l}\text { Capital structure is the combination of third-party capital } \\
\text { (creditors) and equity (shareholders). The company's cost of } \\
\text { capital is the minimum return required by both funders. }\end{array}$ \\
\hline & & B & Tax shield & $\begin{array}{l}\text { Tax Shield refers to the reduction of income tax due to the } \\
\text { deductions allowed in the company's taxable income, } \\
\text { including depreciation, amortization, interest and tax losses. }\end{array}$ \\
\hline & & $\mathrm{C}$ & Tax planning & $\begin{array}{l}\text { Tax planning is the process to obtain a lower tax burden on the } \\
\text { corporate operations, known as tax avoidance. }\end{array}$ \\
\hline \multirow[t]{2}{*}{2} & \multirow{2}{*}{$\begin{array}{l}\text { Theorie } \\
\text { s } \\
\text { related } \\
\text { to the } \\
\text { hypo- }\end{array}$} & A & $\begin{array}{l}\text { Trade-off } \\
\text { theory }\end{array}$ & $\begin{array}{l}\text { In the TOT, the company, encouraged by the debt tax benefit, } \\
\text { resorts to third-party capital to the level on which the costs, } \\
\text { associated with the bankruptcy risks, outweigh this advantage. }\end{array}$ \\
\hline & & B & $\begin{array}{l}\text { Pecking-order } \\
\text { theory }\end{array}$ & $\begin{array}{l}\text { The pecking-order theory (POT) states that there is a hierarchy } \\
\text { in the financing sources, namely: a) internal resources, b) }\end{array}$ \\
\hline
\end{tabular}




\begin{tabular}{|c|c|c|c|c|}
\hline & theses & & & contracting of debt and c) issuance of shares. \\
\hline & & $\mathrm{C}$ & $\begin{array}{l}\text { Bankruptcy } \\
\text { costs }\end{array}$ & $\begin{array}{l}\text { Bankruptcy costs stem from increased debt costs, which result } \\
\text { from a higher probability of bankruptcy. The bankruptcy costs } \\
\text { have two aspects: a) probability of financial distress and, b) } \\
\text { costs inherent to the company's insolvency. }\end{array}$ \\
\hline & & $\mathrm{D}$ & Agency theory & $\begin{array}{l}\text { According to the agency theory, companies form a set of } \\
\text { contracts aiming at maximizing the shareholder's wealth. The } \\
\text { agency problem stems from the conflict of interests between } \\
\text { managers and owners. }\end{array}$ \\
\hline & & $\mathrm{E}$ & Others & $\begin{array}{l}\text { Studies whose hypotheses do not present the theories } \\
\text { contemplated in categories } 2 \mathrm{~A}, 2 \mathrm{~B}, 2 \mathrm{C} \text { and } 2 \mathrm{D} \text {. }\end{array}$ \\
\hline & & A & $\begin{array}{l}\text { Regression } \\
\text { with cross- } \\
\text { section data }\end{array}$ & $\begin{array}{l}\text { The regression with cross-sectional data analyzes the company } \\
\text { data, considering a certain period. }\end{array}$ \\
\hline & & B & $\begin{array}{l}\text { Regression } \\
\text { with panel } \\
\text { data }\end{array}$ & $\begin{array}{l}\text { The regression with panel data analyzes the company data, } \\
\text { considering two or more periods. }\end{array}$ \\
\hline 3 & $\begin{array}{l}\text { Method } \\
\text { used }\end{array}$ & $\mathrm{C}$ & $\begin{array}{l}\text { Simulation } \\
\text { with } \\
\text { computational } \\
\text { methods }\end{array}$ & Refers to models developed by means of computer programs. \\
\hline & & $\mathrm{D}$ & $\begin{array}{l}\text { Application of } \\
\text { questionnaires }\end{array}$ & $\begin{array}{l}\text { Refers to obtaining data or information about characteristics, } \\
\text { actions or opinions of a particular group of people. }\end{array}$ \\
\hline & & $\mathrm{E}$ & Others & Other methods not mentioned in categories $3 \mathrm{~A}, 3 \mathrm{~B}, 3 \mathrm{C}$ and $3 \mathrm{D}$ \\
\hline & & $\mathrm{A}$ & $\begin{array}{l}\text { Effective tax } \\
\text { rate }\end{array}$ & $\begin{array}{l}\text { Effective rate of income tax on taxable income paid by legal } \\
\text { entities. }\end{array}$ \\
\hline & & $\mathrm{B}$ & $\begin{array}{l}\text { Individual's } \\
\text { taxation }\end{array}$ & Taxes incising on individuals \\
\hline & & $\mathrm{C}$ & $\begin{array}{l}\text { Marginal tax } \\
\text { rate }\end{array}$ & $\begin{array}{l}\text { The marginal tax rate (MTR) incorporates the effects of } \\
\text { deductions and tax credits, becoming the rate that the taxpayer } \\
\text { expects to pay on taxable income. }\end{array}$ \\
\hline & & $\mathrm{D}$ & $\begin{array}{l}\text { Interests on } \\
\text { equity }\end{array}$ & $\begin{array}{l}\text { These are interests on shareholders 'equity and they are } \\
\text { deductible in the calculation of corporate taxes. }\end{array}$ \\
\hline & & $\mathrm{E}$ & $\begin{array}{l}\text { Statutory tax } \\
\text { rate }\end{array}$ & Maximum income tax rate paid by companies. \\
\hline 4 & bles of & $\mathrm{F}$ & $\begin{array}{l}\text { Non-financial } \\
\text { tax deductions }\end{array}$ & $\begin{array}{l}\text { These are, for example, depreciation and amortization } \\
\text { expenses, which are deductible from the income tax basis. }\end{array}$ \\
\hline & & $\mathrm{G}$ & $\begin{array}{l}\text { Multinational } \\
\text { companies }\end{array}$ & $\begin{array}{l}\text { Use of more favorable tax conditions, according to the country } \\
\text { (s) where the multinational company operates. }\end{array}$ \\
\hline & & $\mathrm{H}$ & Tax incentives & $\begin{array}{l}\text { These are tax deductions imposed by the government, } \\
\text { depending on the investment made by the companies. }\end{array}$ \\
\hline & & I & Deferred tax & Refers to the balance of taxes that can be offset in the future. \\
\hline & & $\mathbf{J}$ & $\begin{array}{l}\text { Legislation } \\
\text { changes }\end{array}$ & $\begin{array}{l}\text { Changes in tax legislation altering the rules on individual and } \\
\text { legal entities' taxation }\end{array}$ \\
\hline & & $\mathrm{L}$ & $\begin{array}{l}\text { Dividends } \\
\text { taxation }\end{array}$ & Taxation on dividends received by shareholders. \\
\hline & & $\mathrm{M}$ & $\begin{array}{l}\text { Capital gain } \\
\text { taxation }\end{array}$ & Tax on positive variation in asset trading. \\
\hline & Data & A & $\begin{array}{l}\text { Financial } \\
\text { Statements }\end{array}$ & $\begin{array}{l}\text { Financial accounting reports representing the equity and } \\
\text { financial position of companies, at the end of fiscal years. }\end{array}$ \\
\hline 5 & $\begin{array}{l}\text { types } \\
\text { analyze } \\
\text { d }\end{array}$ & B & $\begin{array}{l}\text { Market } \\
\text { information }\end{array}$ & $\begin{array}{l}\text { Data of the companies made available by the market (e.g. } \\
\text { stock price), which are used as a dependent or explanatory } \\
\text { variable in the econometric models. }\end{array}$ \\
\hline
\end{tabular}




\begin{tabular}{|c|c|c|c|c|}
\hline & & $\mathrm{C}$ & $\begin{array}{l}\text { Macroeconomi } \\
\text { c data }\end{array}$ & $\begin{array}{l}\text { Macroeconomic data on the markets in which firms operate } \\
\text { and that are used as a dependent or explanatory variable in } \\
\text { econometric models. }\end{array}$ \\
\hline & & $\mathrm{D}$ & Do not apply & Studies that do not use data. \\
\hline & & $\mathrm{E}$ & Others & Use of data types not considered in categories $5 \mathrm{~A}, 5 \mathrm{~B}$ and $5 \mathrm{C}$ \\
\hline \multirow{6}{*}{6} & \multirow{6}{*}{$\begin{array}{l}\text { Data } \\
\text { origin }\end{array}$} & $\mathrm{A}$ & Global & Works covering two or more countries. \\
\hline & & $\mathrm{B}$ & United States & Data of companies operating in the United States market. \\
\hline & & $\mathrm{C}$ & Europe & Data of companies operating in the European market. \\
\hline & & $\mathrm{D}$ & Ásia/Oceania & $\begin{array}{l}\text { Data of companies operating in the Asian and Oceania } \\
\text { markets. }\end{array}$ \\
\hline & & $\mathrm{E}$ & Others & $\begin{array}{l}\text { Data of companies operating in other countries not included in } \\
\text { categories } 6 \mathrm{~B}, 6 \mathrm{C} \text { and } 6 \mathrm{D} \text {. }\end{array}$ \\
\hline & & $\mathrm{F}$ & Do not apply & Studies not applying data and/or not considering a country. \\
\hline \multirow{4}{*}{7} & \multirow{4}{*}{$\begin{array}{l}\text { Econo- } \\
\text { mic } \\
\text { context }\end{array}$} & $\mathrm{A}$ & $\begin{array}{l}\text { High income } \\
\text { country }^{\mathrm{a}}\end{array}$ & Country with annual per capita income as of US\$12,476. \\
\hline & & $\mathrm{B}$ & $\begin{array}{l}\text { Non-high } \\
\text { income } \\
\text { country }\end{array}$ & $\begin{array}{l}\text { Annual per capita income levels: Low - less than US\$ } 1,025 \text {; } \\
\text { Low average - between US\$ } 1,026 \text { and US\$ 4,035; and High } \\
\text { average- between US } \$ 4,036 \text { and US\$12,475. }\end{array}$ \\
\hline & & $\mathrm{C}$ & Both & Includes all countries. \\
\hline & & $\mathrm{D}$ & Not mentioned & $\begin{array}{l}\text { Studies not presenting a sample and/or not considering a } \\
\text { country. }\end{array}$ \\
\hline \multirow{5}{*}{8} & \multirow{5}{*}{$\begin{array}{l}\text { Period } \\
\text { of } \\
\text { analysis }\end{array}$} & $\mathrm{A}$ & Up to 3 years & Sample with more than 0 and less than 3 years. \\
\hline & & B & $\begin{array}{l}\text { From } 3 \text { to } 5 \\
\text { years }\end{array}$ & Sample with more than 3 and less than 5 years. \\
\hline & & $\mathrm{C}$ & $\begin{array}{l}\text { From } 5 \text { to } 10 \\
\text { years }\end{array}$ & Sample with more than 5 and less than 10 years. \\
\hline & & $\mathrm{D}$ & $\begin{array}{l}\text { More than } 10 \\
\text { years }\end{array}$ & Sample with more than 10 years. \\
\hline & & $\mathrm{E}$ & Do not apply & Studies not presenting a period of analysis. \\
\hline \multirow{2}{*}{9} & \multirow{2}{*}{ Results } & A & $\begin{array}{l}\text { New } \\
\text { perspectives }\end{array}$ & $\begin{array}{l}\text { Studies extending the frontier of knowledge, by means of the } \\
\text { presentation of a new theory, variable/proxy, method or } \\
\text { mathematical model. }\end{array}$ \\
\hline & & $\mathrm{B}$ & $\begin{array}{l}\text { Consistent } \\
\text { with other } \\
\text { papers }\end{array}$ & Studies not presenting new perspectives. \\
\hline \multirow{6}{*}{$\begin{array}{l}1 \\
0\end{array}$} & \multirow{6}{*}{$\begin{array}{l}\text { Avenue } \\
\mathrm{s} \quad \text { for } \\
\text { future } \\
\text { research }\end{array}$} & $\mathrm{A}$ & $\begin{array}{l}\text { Macroeconomi } \\
\text { cs }\end{array}$ & Exploring on macroeconomics determinants. \\
\hline & & $\mathrm{B}$ & Investments & Exploring on investment aspects. \\
\hline & & $\mathrm{C}$ & $\begin{array}{l}\text { Taxable } \\
\text { systems }\end{array}$ & $\begin{array}{l}\text { Exploring the rules and corporate responses on different tax } \\
\text { systems. }\end{array}$ \\
\hline & & $\mathrm{D}$ & Stakeholders & Exploring stakeholders` behavior. \\
\hline & & $\mathrm{E}$ & MTR & Exploring tax incentives and non-tax determinants. \\
\hline & & $\mathrm{F}$ & Zero-leverage & Exploring zero-leverage option. \\
\hline
\end{tabular}

Note $^{a}$ : The ratings and annual per capita income levels for this study are set by the World Bank (2016).

Source: Own.

Additionally, the main aspects - objectives, contributions and conclusions - of the 33 studies analyzed in the final sample, as presented in Table 2, are identified. The order of the studies meets the criterion from the largest to the lowest number of citations on the WoS basis. 


\section{Results}

The analysis of the sample of 33 papers aims at identifying knowledge gaps on the researched topics, based on the following evaluations: a) general data on papers and researchers, b) individual frequency count of each (sub) category and c) frequency count of the combination of (sub) categories.

When analyzing the main researchers of the studies, it is noticed that almost all of them are from high income countries, since 14 of them are from the USA, 5 from Germany, 3 from Canada and 2 from China. Regarding the researched papers, their highest frequency of publication is as follows: Journal of Financial Economics (6), Journal of Corporate Finance (4), Journal of Banking and Finance (2), Review of Financial Studies (2) and others with only 1 article published. As for the total number of citations, the journals with the greatest impact are: Journal of Financial Economics (782), Journal of Corporate Finance (200), Journal of Banking and Finance (137) and Review of Financial Studies (73).

Additionally, it is verified that none of the researchers has more than one paper published and that no university/institution of researchers is associated with more than one article. As for JELs, the most frequent are: G32 (19), H25 (7), G38 (4) and $\mathrm{H} 24$ (4). About the years of publication, in 2014 there are 12, in 2013 and 2015 there are 10 and in 2016 there is only 1 article. Obviously, taking into account that the sample considers the papers with the greatest number of citations between 2013 and 2017, the oldest articles have a larger publication volume. As for the keywords, the most cited groups (see step 7) are: capital structure (37.2\%), taxation (19.2\%), sample type (17.9\%), methodology $(7.7 \%)$, determinants of capital structure $(6.4 \%)$, theories, cost of capital and others (3.8\% each).

Table 2 presents the (sub) categories encodings for the 33 papers examined in this study - see Table 1 . It is worth mentioning that the same category can contain up to 3 subcategories. Therefore, the following frequency count may exceed the total of 33 articles in the sample.

Table 2. Coding of Categories and Subcategories of Articles' Analysis

\begin{tabular}{|l|l|l|l|l|l|l|l|l|l|l|l|}
\hline No. & Title & \multicolumn{7}{|c|}{ Categories (numbers) and subcategories (letters) } \\
\cline { 3 - 11 } & $\mathbf{1}$ & $\mathbf{2}$ & $\mathbf{3}$ & $\mathbf{4}$ & $\mathbf{5}$ & $\mathbf{6}$ & $\mathbf{7}$ & $\mathbf{8}$ & $\mathbf{9}$ & $\mathbf{1 0}$ \\
\hline $\begin{array}{l}\text { Strebula } \\
\text { ev and } \\
\begin{array}{l}\text { Yang } \\
(2013)\end{array}\end{array}$ & $\begin{array}{l}\text { The mystery of zero- } \\
\text { leverage firms }\end{array}$ & A & D & E & C & A & B & A & D & B & B-F \\
\hline $\begin{array}{l}\text { Heider } \\
\text { and } \\
\begin{array}{l}\text { Ljungqv } \\
\text { ist } \\
(2015)\end{array}\end{array}$ & $\begin{array}{l}\text { As certain as debt } \\
\text { and taxes: } \\
\text { Estimating the tax } \\
\text { sensitivity } \\
\text { leverage from state } \\
\text { tax changes }\end{array}$ & A & A & B & C & A & B & A & D & B & C \\
\hline Hasan et & Beauty is in the eye & A & D & B & A-E- & A & B & A & D & B & n.a. \\
\hline
\end{tabular}




\begin{tabular}{|c|c|c|c|c|c|c|c|c|c|c|c|}
\hline $\begin{array}{l}a l \\
(2014)\end{array}$ & $\begin{array}{l}\text { of the beholder: The } \\
\text { effect of corporate } \\
\text { tax avoidance on the } \\
\text { cost of bank loans }\end{array}$ & & & & I & & & & & & \\
\hline $\begin{array}{l}\text { Graham } \\
\text { et al. } \\
(2015)\end{array}$ & $\begin{array}{l}\text { A century of capital } \\
\text { structure: The } \\
\text { leveraging of } \\
\text { corporate America }\end{array}$ & A & B & A & B-E & B & B & A & D & B & A \\
\hline $\begin{array}{l}\text { Feld et } \\
\text { al. } \\
(2013)\end{array}$ & $\begin{array}{l}\text { Capital structure } \\
\text { choice and company } \\
\text { taxation: A meta- } \\
\text { study }\end{array}$ & A & E & E & C & C & B & A & D & B & $\mathrm{E}$ \\
\hline $\begin{array}{l}\text { Custódio } \\
\text { and } \\
\text { Metzger } \\
(2014) \\
\end{array}$ & $\begin{array}{l}\text { Financial expert } \\
\text { CEOs: CEO's work } \\
\text { experience and firm's } \\
\text { financial policies }\end{array}$ & B & B & E & A & A & B & A & D & A & D \\
\hline $\begin{array}{l}\text { Bessler } \\
\text { et al. } \\
(2013)\end{array}$ & $\begin{array}{l}\text { The international } \\
\text { zero-leverage } \\
\text { phenomenon }\end{array}$ & A & D & B & F-I-L & $\begin{array}{l}\text { A- } \\
\text { B }\end{array}$ & A & C & D & B & $\mathrm{F}$ \\
\hline $\begin{array}{l}\text { Hortaçsu } \\
\text { et al. } \\
\text { (2013) }\end{array}$ & $\begin{array}{l}\text { Indirect Costs of } \\
\text { Financial Distress in } \\
\text { Durable Goods } \\
\text { Industries: The Case } \\
\text { of } \\
\text { Manufacturers }\end{array}$ & A & B & D & C & $\begin{array}{l}\text { A- } \\
\text { E }\end{array}$ & B & A & A & B & D \\
\hline $\begin{array}{l}\text { Rapp et } \\
\text { al. } \\
(2014)\end{array}$ & $\begin{array}{l}\text { The value of } \\
\text { financial flexibility } \\
\text { and corporate } \\
\text { financial policy }\end{array}$ & A & D & B & C & A & B & A & D & A & B \\
\hline $\begin{array}{l}\text { Donoho } \\
\text { e (2015) }\end{array}$ & $\begin{array}{lr}\text { The } & \text { economic } \\
\text { effects of } & \text { financial } \\
\text { derivatives } & \text { on } \\
\text { corporate } & \text { tax } \\
\text { avoidance } & \\
\end{array}$ & A & B & A & A & A & B & A & C & B & n.a. \\
\hline $\begin{array}{l}\text { Buettner } \\
\text { and } \\
\text { Wamser } \\
(2013)\end{array}$ & $\begin{array}{l}\text { Internal debt and } \\
\text { multinational profit } \\
\text { shifting: empirical } \\
\text { evidence from firm- } \\
\text { level panel data }\end{array}$ & A & A & B & G & A & A & $\mathrm{C}$ & C & B & A \\
\hline $\begin{array}{l}\text { Faccio } \\
\text { and Xu } \\
(2015)\end{array}$ & $\begin{array}{l}\text { Taxes and Capital } \\
\text { Structure }\end{array}$ & $\mathrm{C}$ & C & B & G-L & A & A & C & D & B & n.a. \\
\hline $\begin{array}{l}\text { Doidge } \\
\text { and } \\
\text { Dyck } \\
(2015) \\
\end{array}$ & $\begin{array}{l}\text { Taxes and corporate } \\
\text { policies: Evidence } \\
\text { from a quasi natural } \\
\text { experiment }\end{array}$ & $\mathrm{C}$ & A & B & $\begin{array}{l}\text { B-H- } \\
\text { J }\end{array}$ & $\begin{array}{l}\text { A- } \\
\text { B }\end{array}$ & E & A & B & B & C \\
\hline $\begin{array}{l}\text { Cohn et } \\
\text { al. } \\
(2014)\end{array}$ & $\begin{array}{l}\text { Do personal taxes } \\
\text { affect } \\
\text { structure? Evidence } \\
\text { from the } 2003 \text { tax } \\
\text { cut }\end{array}$ & $\begin{array}{l}\text { A- } \\
\text { B }\end{array}$ & $\begin{array}{l}\text { A- } \\
\text { B }\end{array}$ & B & $\mathrm{J}$ & $\begin{array}{l}\text { A- } \\
\text { C }\end{array}$ & B & A & D & B & C \\
\hline $\begin{array}{l}\text { Lin and } \\
\text { Flannery }\end{array}$ & $\begin{array}{l}\text { Resource flexibility } \\
\text { and capital structure }\end{array}$ & $\begin{array}{l}\text { A- } \\
\text { B }\end{array}$ & C- & $\mathrm{C}$ & $\begin{array}{l}\text { A-C- } \\
\text { E }\end{array}$ & $\mathrm{C}$ & B & B & C & B & A \\
\hline
\end{tabular}




\begin{tabular}{|c|c|c|c|c|c|c|c|c|c|c|c|}
\hline (2013) & & & $\mathrm{D}$ & & & & & & & & \\
\hline $\begin{array}{l}\text { Chod } \\
\text { and } \\
\text { Zhou } \\
(2014)\end{array}$ & $\begin{array}{l}\text { Corporate tax } \\
\text { aggression and debt }\end{array}$ & $\mathrm{C}$ & A & B & A & A & B & A & B & A & C \\
\hline $\begin{array}{l}\operatorname{Lin} e t \\
\text { al. } \\
(2014)\end{array}$ & $\begin{array}{l}\text { Corporate taxes and } \\
\text { internal borrowing } \\
\text { within multinational } \\
\text { firms }\end{array}$ & $\begin{array}{l}\text { A- } \\
\text { C }\end{array}$ & A & B & G & A & C & A & D & B & A \\
\hline $\begin{array}{l}\text { Egger at } \\
\text { al. } \\
(2014)\end{array}$ & $\begin{array}{l}\text { Corporate tax } \\
\text { aggressiveness, } \\
\text { outside directors, and } \\
\text { debt policy: An } \\
\text { empirical analysis }\end{array}$ & $\begin{array}{l}\text { A- } \\
\text { B- } \\
\text { C }\end{array}$ & A & B & E & A & $\mathrm{F}$ & D & E & B & n.a. \\
\hline $\begin{array}{l}\text { Richar- } \\
\text { dson et } \\
\text { al. } \\
(2014)\end{array}$ & $\begin{array}{l}\text { Debt and taxes: } \\
\text { Evidence from the } \\
\text { real estate industry }\end{array}$ & $\begin{array}{l}\text { A- } \\
\text { B }\end{array}$ & $\begin{array}{l}\text { A- } \\
\text { D }\end{array}$ & B & C & $\mathrm{D}$ & $\mathrm{F}$ & D & E & A & E \\
\hline $\begin{array}{l}\text { Barclay } \\
\text { et } \\
\text { al.(2013 } \\
\text { ) }\end{array}$ & $\begin{array}{l}\text { Capital structure, } \\
\text { corporate taxation } \\
\text { and firm age }\end{array}$ & A & A & A & E & A & C & C & B & B & n.a. \\
\hline $\begin{array}{l}\text { Pfaffer- } \\
\text { mayr et } \\
\text { al. } \\
(2013)\end{array}$ & $\begin{array}{l}\text { Entrepreneurial } \\
\text { finance with equity- } \\
\text { for-guarantee swap } \\
\text { and idiosyncratic } \\
\text { risk }\end{array}$ & $\begin{array}{l}\text { A- } \\
\text { B }\end{array}$ & $\begin{array}{l}\text { A- } \\
\text { C }\end{array}$ & C & $\begin{array}{l}\text { C-E- } \\
M\end{array}$ & $\mathrm{D}$ & $\mathrm{F}$ & D & E & B & n.a. \\
\hline $\begin{array}{l}\text { Wang et } \\
\text { al. } \\
(2015)\end{array}$ & $\begin{array}{l}\text { Collateral, Taxes, } \\
\text { and Leverage }\end{array}$ & A & A & B & A & A & $\mathrm{F}$ & C & D & A & A-B \\
\hline $\begin{array}{l}\text { Li et al. } \\
\text { (2016) }\end{array}$ & $\begin{array}{l}\text { Dynamic optimal } \\
\text { capital structure with } \\
\text { regime switching }\end{array}$ & $\begin{array}{l}\text { A- } \\
\text { B }\end{array}$ & A & $\mathrm{C}$ & $\mathrm{H}$ & $\mathrm{D}$ & $\mathrm{F}$ & $\mathrm{D}$ & E & A & n.a. \\
\hline $\begin{array}{l}\text { Elliott } \\
\text { and } \\
\text { Shen } \\
(2015)\end{array}$ & $\begin{array}{l}\text { Leasing decisions } \\
\text { and } \\
\text { constraints: } \\
\text { Empredit } \\
\text { on a sample of } \\
\text { Italian firms }\end{array}$ & $\begin{array}{l}\text { A- } \\
\text { C }\end{array}$ & $\begin{array}{l}\text { A- } \\
\text { B }\end{array}$ & A & A & A & C & A & A & A & n.a. \\
\hline $\begin{array}{l}\text { Cosci et } \\
\text { al. } \\
(2015)\end{array}$ & $\begin{array}{l}\text { Factors determining } \\
\text { the corporate capital } \\
\text { structure in the } \\
\text { Czech Republic from } \\
\text { the perspective of } \\
\text { business entities }\end{array}$ & $\begin{array}{l}\text { A- } \\
\text { B- } \\
\text { C }\end{array}$ & $\begin{array}{l}\text { A- } \\
\text { B }\end{array}$ & D & A & $\begin{array}{l}\text { A- } \\
\text { C }\end{array}$ & C & A & E & $\mathrm{B}$ & n.a. \\
\hline $\begin{array}{l}\text { Strý- } \\
\text { čková } \\
(2015)\end{array}$ & $\begin{array}{l}\text { How do capital } \\
\text { structure policies of } \\
\text { emerging markets } \\
\text { differ from those of } \\
\text { developed } \\
\text { economies? Survey } \\
\text { evidence from Korea }\end{array}$ & A & $\begin{array}{l}\text { A- } \\
\text { B- } \\
\text { D }\end{array}$ & D & $\begin{array}{l}\text { B-G- } \\
M\end{array}$ & $\begin{array}{l}\text { A- } \\
\text { C }\end{array}$ & A & C & A & B & n.a. \\
\hline $\begin{array}{l}\text { Lee } \quad \text { et } \\
\text { al. }\end{array}$ & $\begin{array}{l}\text { Corporate } \\
\text { deductibility }\end{array}$ & A & D & C & $\mathrm{H}$ & $\mathrm{D}$ & $\mathrm{F}$ & D & E & A & A \\
\hline
\end{tabular}




\begin{tabular}{|c|c|c|c|c|c|c|c|c|c|c|c|}
\hline (2014) & $\begin{array}{ll}\text { provisions } & \text { and } \\
\text { managerial } & \\
\text { incentives } & \\
\end{array}$ & & & & & & & & & & \\
\hline $\begin{array}{l}\text { Koethen } \\
\text { buerger } \\
\text { and Sti- } \\
\text { mmel- } \\
\text { mayr } \\
(2014)\end{array}$ & $\begin{array}{lr}\text { Financial } & \text { leverage } \\
\text { and } & \text { corporate } \\
\text { taxation: } & \text { evidence } \\
\text { from } & \text { German } \\
\text { corporate } & \text { tax return } \\
\text { data } & \end{array}$ & A & A & A & $\mathrm{A}-\mathrm{C}$ & A & C & A & B & B & n.a. \\
\hline $\begin{array}{l}\text { Dwenge } \\
\mathrm{r} \quad \text { and } \\
\text { Steiner } \\
(2014)\end{array}$ & $\begin{array}{lr}\text { Effects of ultimate } \\
\text { ownership structure } \\
\text { and corporate tax on } \\
\text { capital structures: } \\
\text { Evidence } \\
\text { Taiwan }\end{array}$ & A & D & B & A-B & A & $\mathrm{D}$ & A & D & B & B \\
\hline $\begin{array}{l}\text { Lee and } \\
\text { Kuo } \\
(2014)\end{array}$ & $\begin{array}{l}\text { How did the notional } \\
\text { interest deduction } \\
\text { affect Belgian SMEs' } \\
\text { capital structure? }\end{array}$ & A & B & B & D & A & C & A & A & B & A \\
\hline $\begin{array}{l}\text { Van } \\
\text { Campen } \\
\text { hout and } \\
\text { Van } \\
\text { Cane- } \\
\text { ghem } \\
(2013) \\
\end{array}$ & $\begin{array}{l}\text { A nonzero-sum } \\
\text { game approach to } \\
\text { convertible bonds: } \\
\text { tax benefit, } \\
\text { bankruptcy cost, and } \\
\text { early/late calls }\end{array}$ & A & $\begin{array}{l}\text { A- } \\
\text { D }\end{array}$ & C & E-H & D & $\mathrm{F}$ & D & E & B & D \\
\hline $\begin{array}{l}\text { Chen et } \\
\text { al. } \\
(2013)\end{array}$ & $\begin{array}{l}\text { The evolution of } \\
\text { capital structure and } \\
\text { operating } \\
\text { performance after } \\
\text { leveraged buyouts: } \\
\text { Evidence from U.S. } \\
\text { corporate tax returns }\end{array}$ & $\mathrm{C}$ & D & E & A & A & B & A & D & B & B \\
\hline $\begin{array}{l}\text { Serrasqu } \\
\text { eiro and } \\
\text { Nunes } \\
(2014)\end{array}$ & $\begin{array}{l}\text { Financing behaviour } \\
\text { of Portuguese SMEs } \\
\text { in hotel industry }\end{array}$ & A & $\begin{array}{l}\text { A- } \\
\text { B }\end{array}$ & B & A-F & A & C & A & C & B & n.a. \\
\hline
\end{tabular}

Note: n.a.: non applicable

Source: Own.

Figure 1 shows that the topic of capital structure and cost - subcategory A - is the main focus for the researchers, with the predominant theme in the papers analyzed $(62 \%)$, followed by planning studies $(21 \%)$ and tax shields $(17 \%)$ as subcategories $\mathrm{C}$ and B. In turn, Figure 2 indicates that there is a marked predominance for TOT (45\%), which deals with the optimization of the capital structure, followed by agency theories $(11 \%)$, POT $(9 \%)$ and bankruptcy costs $(3 \%)$. Figure 3 shows that most of the studies uses regression with panel data $(52 \%)$ and with cross-section (15\%), followed by computational methods (5\%) and questionnaires (3\%). 
Figure 1. Category 1: main topic/focus of study

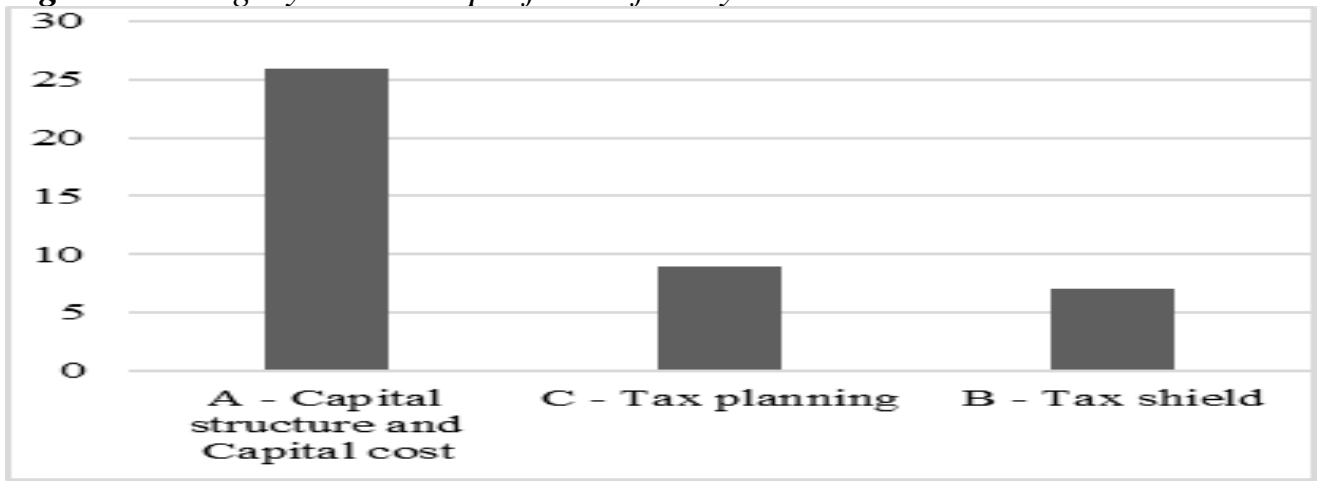

Source: Own.

Figure 2. Category 2: theories

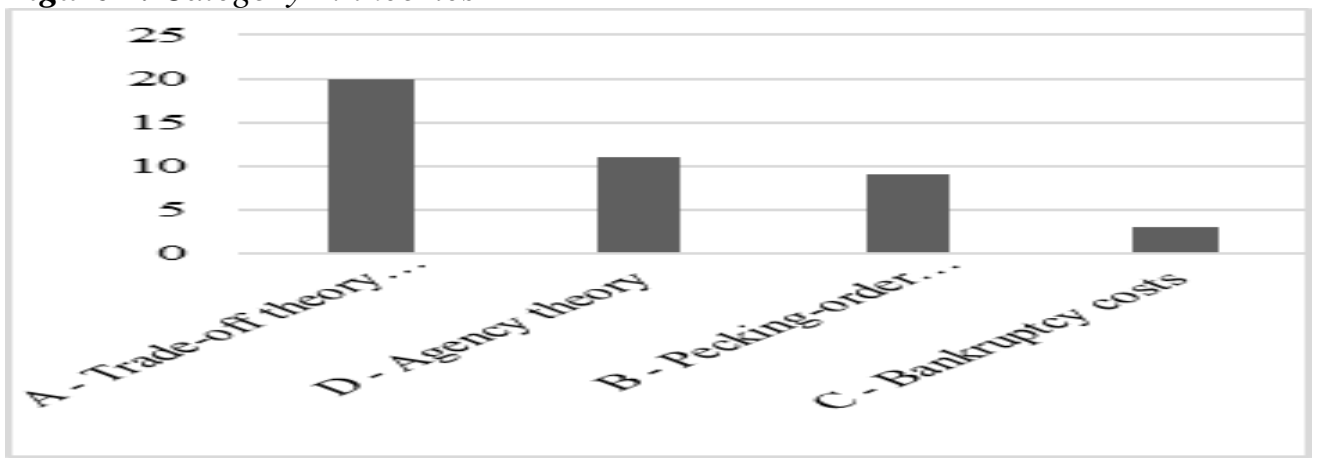

Source: Own.

Figure 3. Category 3: method used

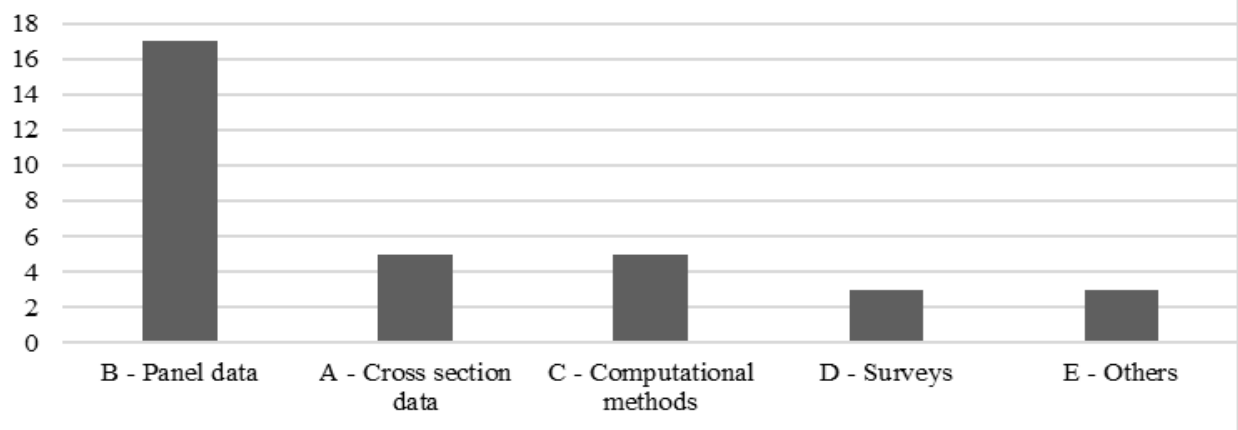

\section{Source: Own}

Figure 4 , is observed a diversification of the variables used in the studies in relation to the topic of taxes, highlighting, effective tax rate (25\%), MTR (15\%), statutory tax rate $(13 \%)$, among others. 
Figure 4. Category 4: variables of interest

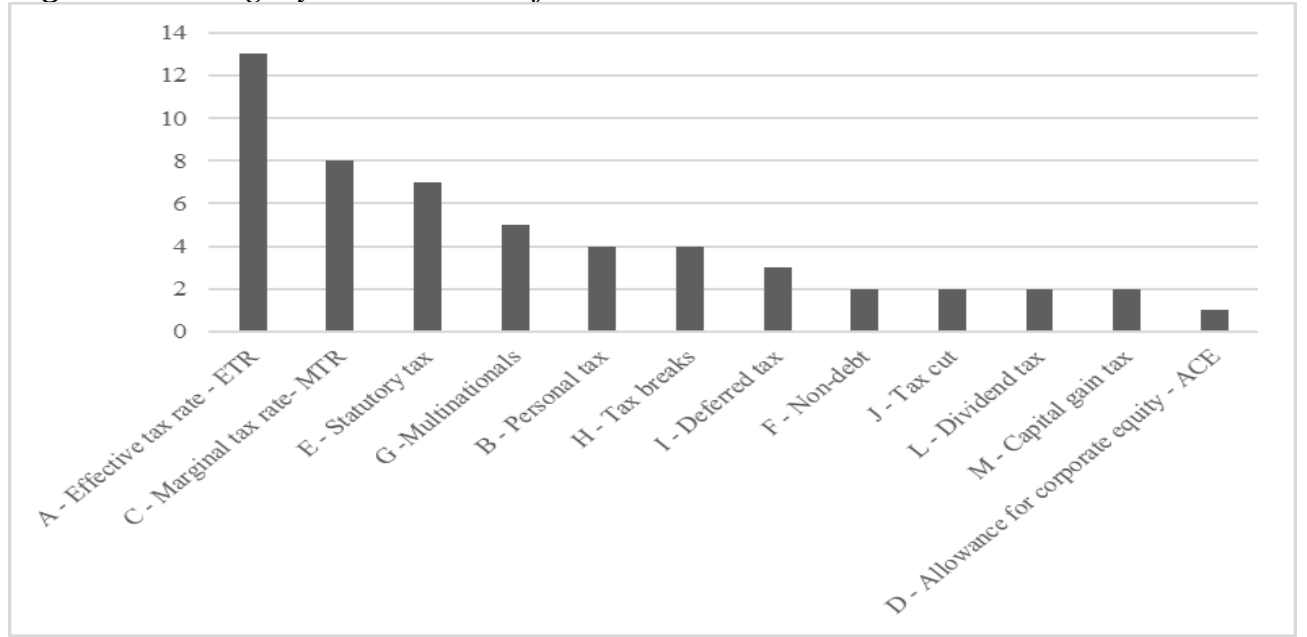

Source: Own.

In Figure 5, most of the works use the financial statements (25\%), some of them use mathematical models without using any financial or economic data - not applicable (13\%). Regarding Figure 6, studies are more concentrated in the United States (39\%) and Europe $(21 \%)$. It is noteworthy that there are few works with a global basis $(12 \%)$. Figure 7 , a low number of papers with samples of non-high income countries (3\%) is identified, which characterizes an opportunity for studies in these regions. As for Figure 8, there is a higher incidence of studies with more than 10 years $(42 \%)$.

Figure 5. Category 5: data types analyses

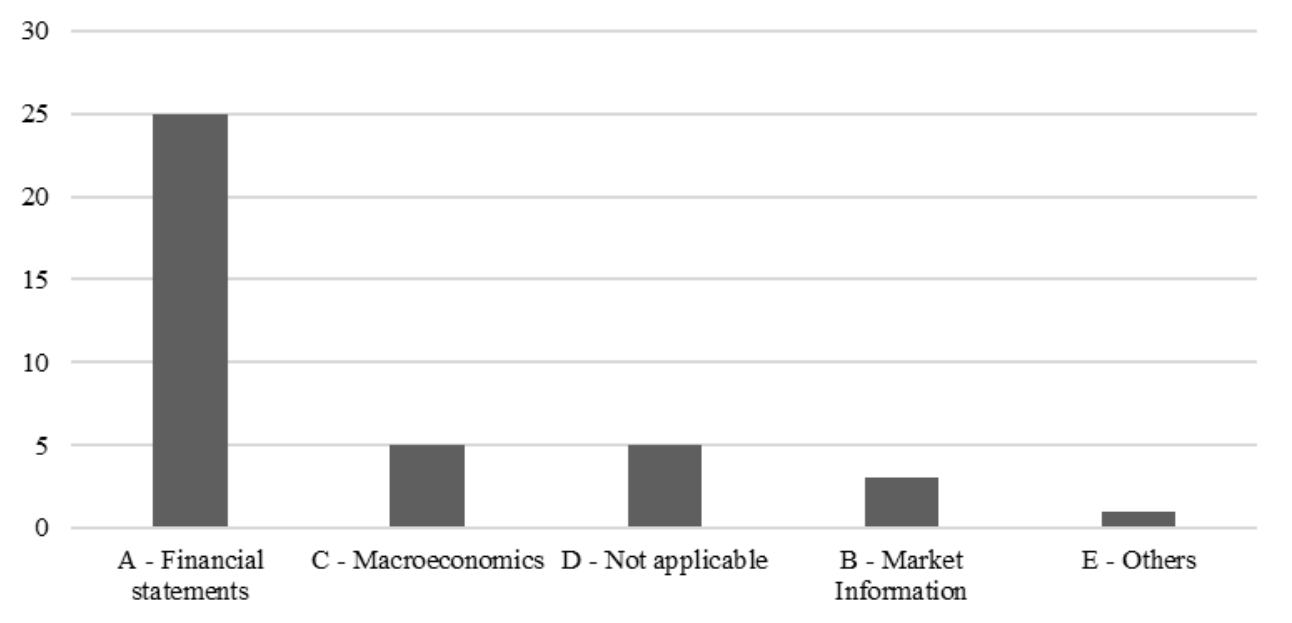

Source: Own. 
Figure 6. Category 6: data origem

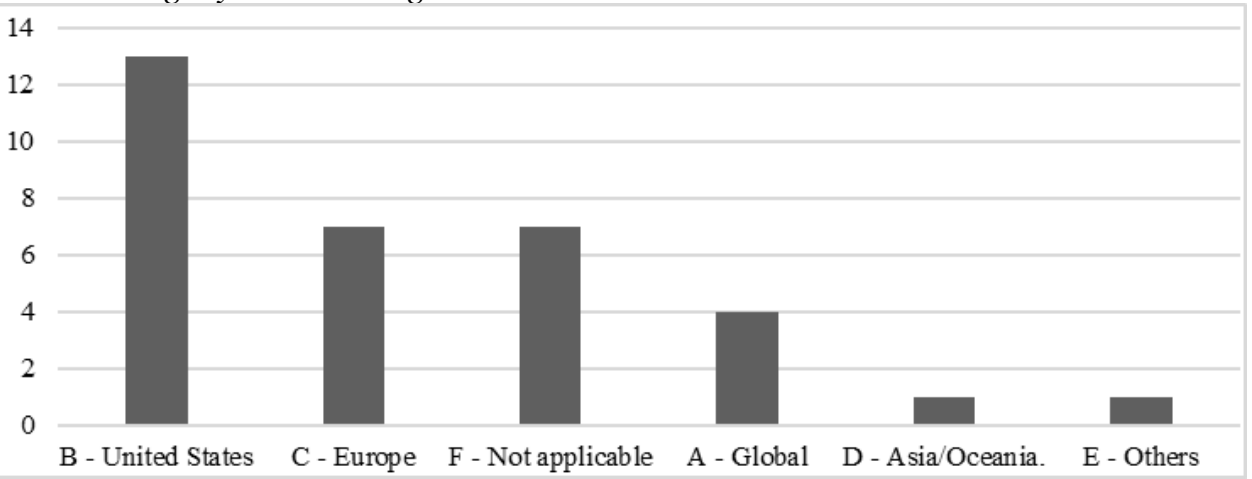

Source: Own.

Figure 7. Category 7: economic context

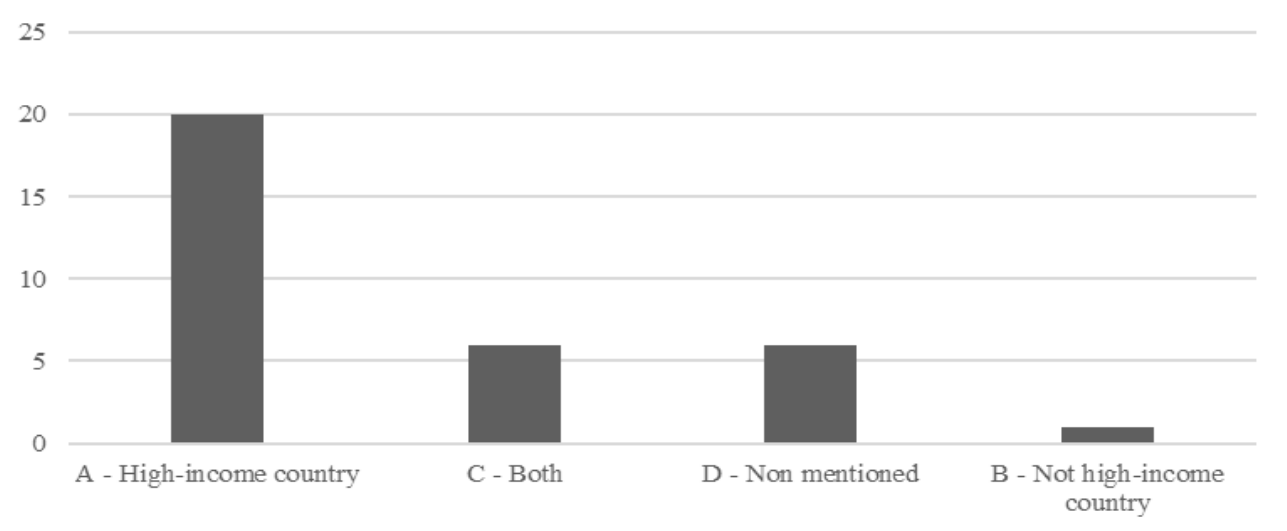

\section{Source: Own.}

Figure 8. Category 8: period of analysis

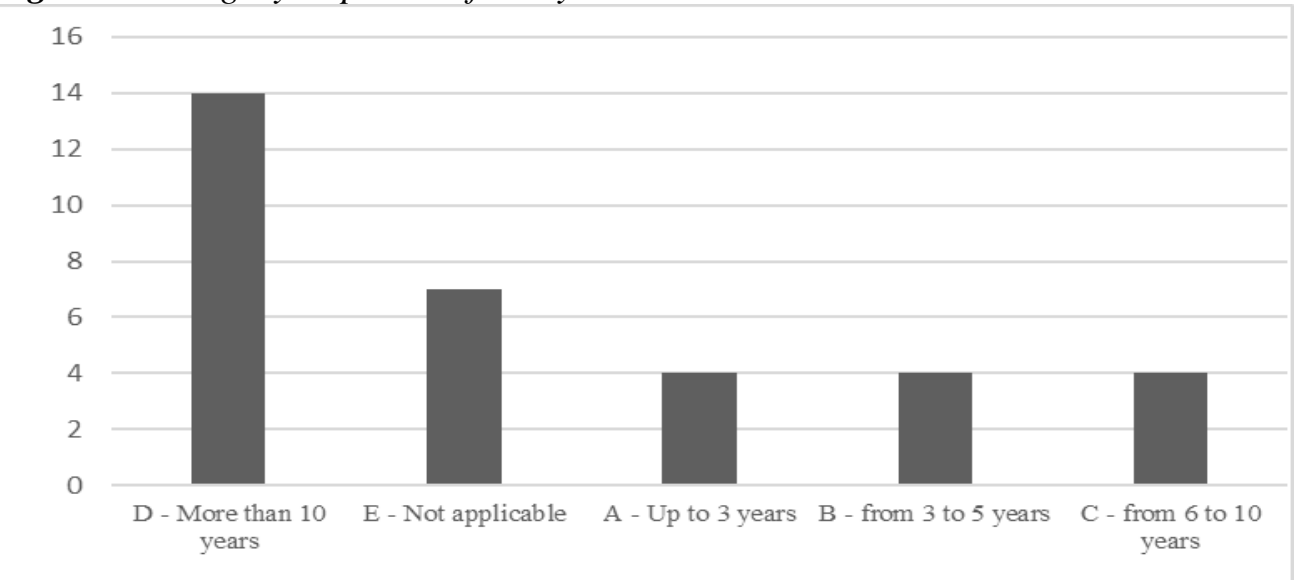

Source: Own. 
Figure 9 shows that $76 \%$ of the studies of the sample present conclusions consistent with other papers in the literature. It means that only $24 \%$ effectively add new contribution to the academy and/or society, which indicates a possibility of scoping in new researches, such as Rapp et al. (2014) who propose an approach to estimate the financial flexibility from the perspective of the shareholders.

Figure 9. Category 9: results

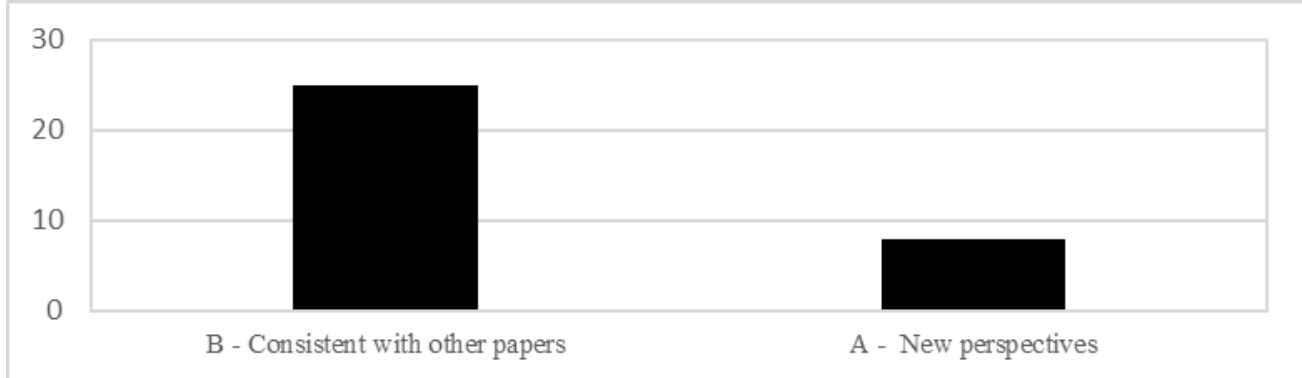

\section{Source: Own.}

Figure 10 presents the results of avenues for future research suggested by the authors of the review: macroeconomics (29\%); investments $(21 \%)$; taxable systems (17\%); stakeholders (17\%); MTR (8\%) and zero-leverage (8\%).

Figure 10. Category 10: avenues for future research

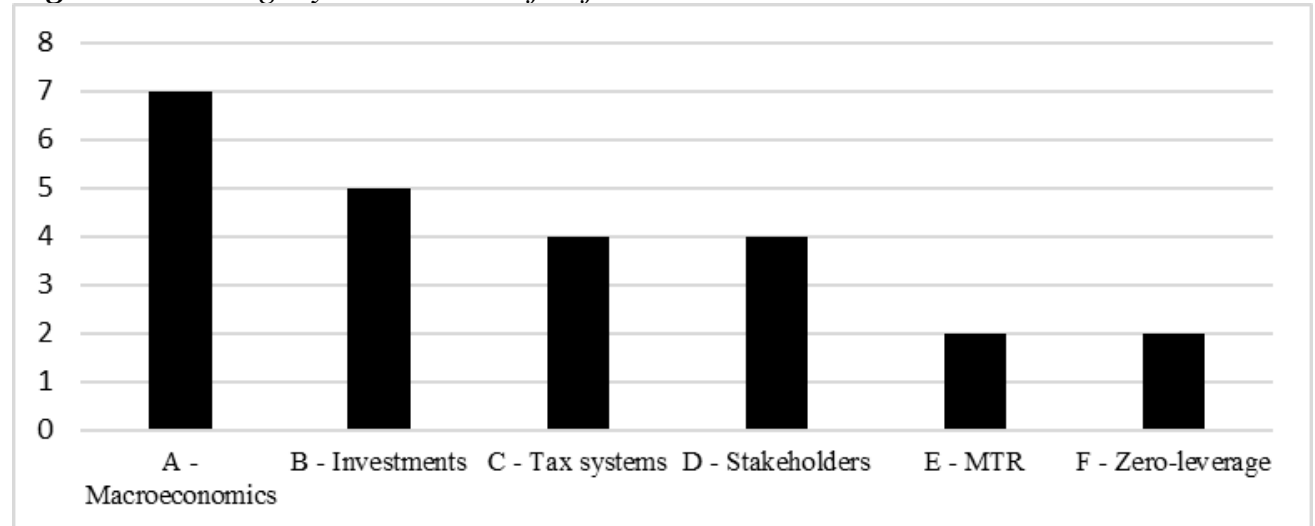

\section{Source: Own.}

In turn, Figure 11 points out the most and least recurrent themes in the sample analyzed, suggesting possible knowledge gaps to be filled by other researchers. Regarding category 1 , despite a relative recurrence of studies on capital structure and tax benefit, supported by the TOT, there is not the same interest about the impact of tax planning on corporate indebtedness decisions. As for category 2, the opportunity to study TOT by considering the aspects of bankruptcy cost and financial distress is interesting to highlight. For Chen et al. (2013), credit risk has a considerable impact on decision making. This issue is highlighted by the global economic post-crisis 
period, in which credit dynamics are affected by a disruption to the expansionary economic model, in place until 2008. The review results indicate that researchers are not aware of this important aspect of the balance. Generally, the test of this theory is limited to the aspect of the tax benefit.

With respect to category 3 , there is a clear preference for the regression model with panel data. However, there is the opportunity to apply other methods such as differences in differences. It applies to casual exogenous events, such as tax reforms implemented by countries and their impact on the capital structure of companies. In category 4, the researchers` option is for tax variables, mainly the effective tax rate, that are more directly associated with the companies and individuals. This fact presents an opportunity to use other variables equally relevant to tax and capital structure issues, such as interest on equity, tax benefits not resulting from financial expenses, dividend payments, capital gains and changes in tax legislation. This is an important finding of the research, as determining the proxy that identifies taxes is decisive in defining the relationship in companies' capital structure. MTR is the proxy developed by Graham (1996a; 1996b), which considers the marginal effect prior to financing decisions to avoid endogeneity problems. According to the author, the results indicate that the simulated tax rate, even being difficult to calculate, is the best proxy available for the "true" marginal tax rate. For Dwenger and Steiner (2014), MTR reflects a firm's debt and nondebt tax shields and it takes into account tax loss carry-forwards and carry-backs.

In category 5 , there is a concentration on financial statements data, rising ground for research considering market data at micro and macroeconomic levels. About the sample used, category 6 indicates a concentration of studies on North American and European companies, which opens room for research on companies located in Asia, Oceania, Africa, Central and South America. In fact, a single study on Asian companies and none on companies located in Africa or Latin America, are identified. Regarding category 7 , in line with the results of category 5 , the researches have as economic context high-income countries. This ratifies the window of opportunities for research about low-income countries, contributing to the improvements of these economies. This perception also stems from the fact that there is a greater geographical diversification of emerging countries, such as China, India, Russia, Chile, Colombia, Peru, among others. About category 8, the occurrence of long-term research, with over 10-year data, is pointed out.

However, sometimes, tax issues have an immediate impact on corporate financing decisions. Category 9 confirms the need for studies transcending the validation of models and theories already widely researched and adding new perspectives to the frontier of the existing knowledge like Richardson et al.(2014) examining the influence of corporate tax aggressiveness on corporate debt policy. Finally, in category 10, 21 papers present the authors' suggestions for future research. This aspect is relevant, since researchers' inferences identify gaps concerning the ongoing theme. The most relevant topics are macroeconomics; investments; taxable systems; 
stakeholders; MTR and zero-leverage. The analyses related to Figure 11 can be considered individually or in combination for defining the scope of new researches. For Jabbour (2013), the combined approach tends to produce even more original results with greater potential to contribute to the advancement of the current knowledge threshold on related topics.

\section{Legend (Figure 11):}

The most frequently addressed category of each classification item

The secondary categories of each classification item =

Category to be prioritized in the research agenda $=$

Categories to be additionally considered in the research agenda

$=$

\section{Conclusion}

This study performs a systematic review of the corporate finance literature on tax and capital structure topics. Its relevance is due to the ongoing tax reform in some countries - including the one that is happening in the United States since 2017 - and its impact all over the world. The qualitative analysis provided by the systematic review is a valuable tool to prioritize important contributions, based on the behavior of citations. Citations are influenced by scientific factors such as the magnitude of the study and by non-scientific ones such as author's knowledge of the literature. Therefore, the analyzed sample considers the 33 most cited articles between 2013 and 2017 and published in the main international financial journals. Thus, it intends to be sufficiently robust to support the inferences presented.

The results bring up different perspectives about the influence of taxes on corporate capital structure. For instance, MM theory does not consider some market frictions on the assumptions of their propositions such as bankruptcy and default costs, which continue increasing as debt grows. This could be one of the reasons for having few studies in the sample about this subject (3\%). The Organisation for Economic Cooperation and Development (OECD) is expressing its concern about what shall be learned from the latest economic crisis to avoid such painful consequences for economy. Moreover, an inappropriate use of tax proxies is identified in $38 \%$ of the sample. The complexity in simulating MTR seems to lead researchers to use an alternative tax variables with endogeneity problems - the effective tax rate - or in relation to the projected rate by the company in its decision making - the statutory tax rate. However, no matter how difficult is the calculation, the analysis of the relationship between taxes and capital structure should consider MTR proxy, since it is more accurate for the next tax rate of income unit. Furthermore, under governments' perspective, MTR proxy may help to understand tax rates tendency, considering the recent international competition increase for investment, and also in assessing the introduction of allowance for corporate equity (ACE), in line with International Monetary Fund (IMF) and other global institutions`studies. 
Figure 11. Distribution of the analysis`classification and categories

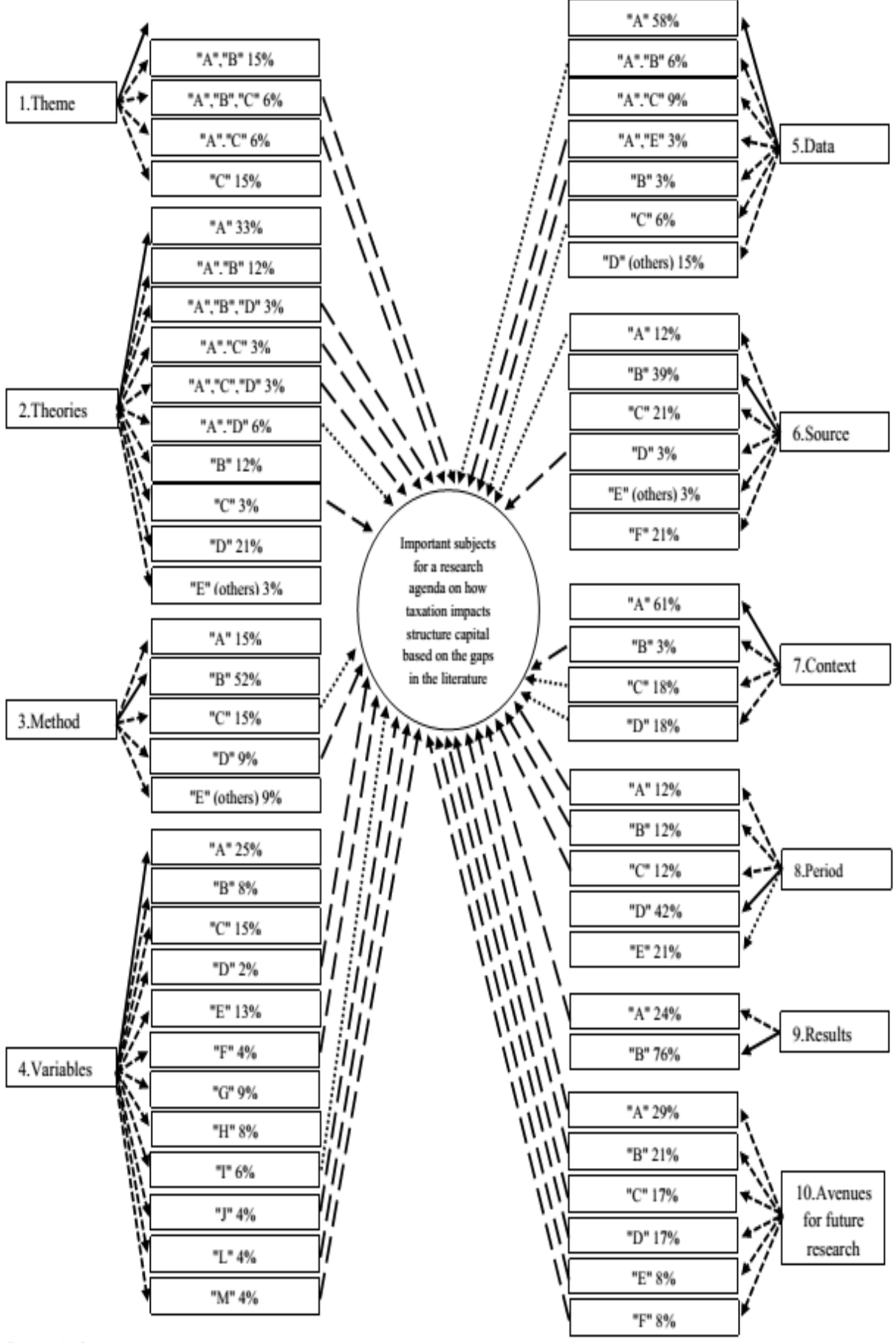

Source: Own. 
This study also identifies the predominance of research and researchers with highincome countries origin. This fact results in the absence of studies among the world's largest economies, which may be the protagonists in the coming decades - e.g. China, Russia, India, Brazil, etc (Marino et al., 2016). In addition, there is also a special highlight to other knowledge gaps, namely: tax incentives; study of TOT, considering the aspects of bankruptcy cost and financial distress; application of other methods, such as differences in differences for analysis of tax reforms implemented by governments and their impact on the companies' capital structure; and the use of variables not directly related to individuals and legal entities' tax rates, such as interest on shareholders' equity, capital gains and changes in tax legislation. Likewise, the results point to a literature gap about banks'participation in government policies and corporate planning.

Concerning the avenues for future research, the following themes are suggested in each subcategory. As for macroeconomic determinants, the authors propose the analysis of policy, efficiency and tax stimuli aspects; interaction among government, banks and companies; volatility demand; incentives for productivity and multinationals' domestic and external fund-raising. There is also a lack of research about the dynamics between financing and investment decisions; mergers and acquisitions (M\&A), as well as specific country's factors. On taxable systems issues, they propose an investigation about how companies respond to drastic cuts; double taxation; personal taxes and tax avoidance. Managers and advisors' behaviors are highlighted too. It is important to analyze their background or even their own interests on investment decisions and dividend distribution. Likewise, there is a concern about the accepted risk limit by stakeholders in a bankruptcy or financial distress scenario. Moreover, they suggest the use of MTR as a proxy of the marginal tax incentive in dynamic models. Finally, there is an increasing interest about the zero-leverage capital structure.

The complexity of legislations and the interdisciplinarity of taxes pose a challenge to researchers who seek to understand their influence on the financing decisions of firms. A first obstacle to research is the very absence of papers presenting the state of the art on the subject. This being so, this study intends to contribute and to inspire more research related to the topics mentioned. As a limitation, the findings presented are subject to the set of journal papers that meet the established selection criteria. In addition, the analysis of more recent articles may have excluded the examination of equally relevant previous articles, including the seminal ones.

\section{References:}

Arvanitis, S., Tzigkounaki, I.S., Stamatopoulos, T.V., Thalassinos, I.E. 2012. Dynamic approach of capital structure of European shipping companies. International Journal of Economic Sciences and Applied Research, 5(3), 33-63.

Barboza, F., Kimura, H., Sobreiro, V.A., Basso, L.F.C. 2016. Credit Risk: from a systematic literature review to future directions. Corporate Ownership and Control, 13(3), 326-346. 
Barclay, M.J., Heitzman, S.M., Smith, C.W. 2013. Debt and taxes: Evidence from the real estate industry. Journal of Corporate Finance, 20(2), 74-93.

Bessler, W., Drobetz, W., Haller, R., Meier, I. 2013. The international zero-leverage phenomenon. Journal of Corporate Finance, 23(5), 196-221.

Bornmann, L., Mutz, R., Daniel, H.D. 2010. A reliability-generalization study of journal peer reviews: A multilevel meta-analysis of inter-rater reliability and its determinants. PloS One, 5(12), 1-6.

Buettner, T., Wamser, G. 2013. Internal debt and multinational profit shifting: empirical evidence from firm-level panel data. National Tax Journal, 66(1), 63-95.

Chen, N., Dai, M., Wan, X. 2013. A nonzero-sum game approach to convertible bonds: tax benefit, bankruptcy cost, and early/late calls. Mathematical Finance, 23(1), 57-93.

Chod, J., Zhou, J. 2014. Resource flexibility and capital structure. Management Science, 60(3), 708-729.

Cohn, J.B., Mills, L.F., Towery, E.M. 2014. The evolution of capital structure and operating performance after leveraged buyouts: Evidence from US corporate tax returns. Journal of Financial Economics, 111(2), 469-494.

Cosci, S., Guida, R., Meliciani, V. 2015. Leasing decisions and credit constraints: Empirical analysis on a sample of Italian firms. European Financial Management, 21(2), 377-398.

Custódio, C., Metzger, D. 2014. Financial expert CEOs: CEO's work experience and firm's financial policies. Journal of Financial Economics, 114(1), 125-154.

DeAngelo, H., Masulis, R.W. 1980. Optimal capital structure under corporate and personal taxation. Journal of Financial Economics, 8(1), 3-27.

Denyer, D., Tranfield, D. 2009. Producing a systematic review. In D.A. Buchanan, A. Bryman, The Sage handbook of organizational research methods. Thousand Oaks, CA. SAGE Publications.

Doidge, C., Dyck, A. 2015. Taxes and corporate policies: evidence from a quasi natural experiment. Journal of Finance, 70(1), 45-89.

Donohoe, M.P. 2015. The economic effects of financial derivatives on corporate tax avoidance. Journal of Accounting and Economics, 59(1), 1-24.

Dwenger, N., Steiner, V. 2014. Financial leverage and corporate taxation: Evidence from German corporate tax return data. International Tax and Public Finance, 21(1), 1-28.

Egger, P., Keuschnigg, C., Merlo, V., Wamser, G. 2014. Corporate taxes and internal borrowing within multinational firms. American Economic Journal: Economic Policy, 6(2), 54-93.

Elliott, R.J., Shen, J. 2015. Dynamic optimal capital structure with regime switching. Annals of Finance, 11(2), 199-220.

Erel, I., Myers, S.C., Read, J.A. 2015. A theory of risk capital. Journal of Financial Economics, 118(3), 620-635.

Faccio, M., Xu, J. 2015. Taxes and capital structure. Journal of Financial and Quantitative Analysis, 50(3), 277-300.

Fama, E.F. 2011. My life in finance. Annual Review of Financial Economics, 3(1), 1-15.

Feld, L.P., Heckemeyer, J.H., Overesch, M. 2013. Capital structure choice and company taxation: A meta-study. Journal of Banking and Finance, 37(8), 2850-2866.

Graham, J.R. 1996a. Debt and the marginal tax rate. Journal of Financial Economics, 41(1), 41-73.

Graham, J.R. 1996b. Proxies for the corporate marginal tax rate. Journal of Financial Economics, 42(2), 187-221.

Graham, J.R., Leary, M.T., Roberts, M. 2015. A century of capital structure: the leveraging of corporate America. Journal of Financial Economics, 118(3), 658-683. 
Hasan, I., Hoi, C.K., Wu, Q., Zhang, H. 2014. Beauty is in the eye of the beholder: the effect of corporate tax avoidance on the cost of bank loans. Journal of Financial Economics, 113(1), 109-130.

Heider, F., Ljungqvist, A. 2015. As certain as debt and taxes: estimating the tax sensitivity of leverage from state tax changes. Journal of Financial Economics, 118(3), 684-712.

Hortaçsu, A., Matvos, G., Syverson, C., Venkataraman, S. 2013. Indirect costs of financial distress in durable goods industries: The case of auto manufacturers. The Review of Financial Studies, 26(5), 1248-1290.

Koethenbuerger, M., Stimmelmayr, M. 2014. Corporate deductibility provisions and managerial incentives. Journal of Public Economics, 111(3), 120-130.

Inger, K.K. 2013. Relative valuation of alternative methods of tax avoidance. The Journal of the American Taxation Association, 36(1), 27-55.

Jabbour, C.J.C. 2013. Environmental training in organizations: from a literature review to a framework for future research. Resources, Conservation and Recycling, 74(1), 144-155.

Jędrzejowska-Schiffauer, I., Schiffauer, P., Thalassinos, I.E. 2019. EU Regulatory Measures Following the Crises: What Impact on Corporate Governance of Financial Institutions? European Research Studies Journal, 22(3), 432-456.

Lee, C.F., Kuo, N.T. 2014. Effects of ultimate ownership structure and corporate tax on capital structures: Evidence from Taiwan. International Review of Economics and Finance, 29(1), 409-425.

Lee, H., Oh, S., Park, K. 2014. How do capital structure policies of emerging markets differ from those of developed economies? Survey evidence from Korea. Emerging Markets Finance and Trade, 50(2), 34-72.

Li, S., Whited, T.M., Wu, Y. 2016. Collateral, taxes, and leverage. The Review of Financial Studies, 29(6), 1453-1500.

Liapis, J.K., Politis, D.E., Ntertsou, D., Thalassinos, I.E. 2020. Investigating the Relationship between Tax Revenues and Tax Ratios: An Empirical Research for Selected OECD Countries. International Journal of Economics and Business Administration, 8(1), 215229. DOI: $10.35808 /$ ijeba/420.

Lin, L., Flannery, M.J. 2013. Do personal taxes affect capital structure? Evidence from the 2003 tax cut. Journal of Financial Economics, 109(2), 549-565.

Lin, S., Tong, N., Tucker, A.L. 2014. Corporate tax aggression and debt. Journal of Banking and Finance, 40(C), 227-241.

Marino, P.D.B.L.P., Soares, R.A., Luca, M.M.M.D., Vasconcelos, A.C.D. 2016. Global Governance Indicators: how they relate to the socioeconomic indicators of the Brics countries. Revista de Administração Pública, 50(5), 721-744.

Miller, M.H. 1977. Debt and taxes. The Journal of Finance, 32(2), 261-275.

Modigliani, F., Miller, M.H. 1958. The cost of capital, corporation finance and the theory of investment. The American Economic Review, 48(3), 261-297.

Modigliani, F., Miller, M.H. 1963. Corporate income taxes and the cost of capital: a correction. The American Economic Review, 53(3), 433-443.

Myers, S.C. 1984. The capital structure puzzle. Journal of Finance, 39(3), 575-592.

Myers, S.C., Majluf, N.S. 1984. Corporate financing and investment decisions when firms have information that investors do not have. Journal of Financial Economics, 13(2), 187221.

Myers, S.C., McConnell, J., Peterson, A., Roebuck, S., Soter, D., Stewart, S., Stern, J. 1998. Vanderbilt University roundtable on the capital structure puzzle. Journal of Applied Corporate Finance, 11, 8-24. 
Nazário, R.T.F., Silva, J.L., Sobreiro, V.A., Kimura, H. 2017. A literature review of technical analysis on stock markets. The Quarterly Review of Economics and Finance, 66(C), 115126.

Pfaffermayr, M., Stoeckl, M., Winner, H. 2013. Capital structure, corporate taxation and firm age. Fiscal Studies, 34(1), 109-135.

Rapp, M.S., Schmid, T., Urban, D. 2014. The value of financial flexibility and corporate financial policy. Journal of Corporate Finance, 29(6), 288-302.

Richardson, G., Lanis, R., Leung, S.C.M. 2014. Corporate tax aggressiveness, outside directors, and debt policy: An empirical analysis. Journal of Corporate Finance, 25(2), 107-121.

Serrasqueiro, Z., Nunes, P.M. 2014. Financing behavior of Portuguese SMEs in hotel industry. International Journal of Hospitality Management, 43(8), 98-107.

Strebulaev, I.A., Yang, B. 2013. The mystery of zero-leverage firms. Journal of Financial Economics, 109(1), 1-23.

Strýčková, L. 2015. Factors determining the corporate capital structure in the Czech Republic from the perspective of business entities. E+M Ekonomie a Management, 1(2), 40-57.

Tranfield, D., Denyer, D., Smart, P. 2003. Towards a methodology for developing evidence-informed management knowledge by means of systematic review. British Journal of Management, 14(3), 207-222.

Van Campenhout, G., Van Caneghem, T. 2013. How did the notional interest deduction affect Belgian SMEs' capital structure? Small Business Economics, 40(2), 351-373.

Wang, H., Yang, Z., Zhang, H. 2015. Entrepreneurial finance with equity-for-guarantee swap and idiosyncratic risk. European Journal of Operational Research, 241(3), 863-871.

World Bank. 2016. New country classifications by income level: 2016-2017. Recovered from https://blogs.worldbank.org/opendata/new-country-classifications-2016. 